\title{
Radiocesium contamination of cetaceans stranded along the coast of Hokkaido, Japan, and an estimation of their travel routes
}

\author{
Tuguya Nakamura ${ }^{1}$, Osamu Kimura ${ }^{2}$, Ayaka Matsuda ${ }^{3}$, Takashi Matsuishi ${ }^{3}$, \\ Mari Kobayashi ${ }^{4}$, Tetsuya Endo ${ }^{2, *}$ \\ ${ }^{1}$ Hokkaido Pharmaceutical Association Public Health Examination Center, 1-8-6-6 Hiragishi, Toyohira-Ku, Sapporo, \\ Hokkaido 062-0931, Japan \\ ${ }^{2}$ School of Pharmaceutical Sciences, Health Sciences University of Hokkaido, 1757 Kanazawa, Ishikari-Tobetsu, \\ Hokkaido 061-0293, Japan \\ ${ }^{3}$ Faculty of Fisheries Sciences, Hokkaido University, 3-1-1 Minato-cho, Hakodate, Hokkaido 041-8611, Japan \\ ${ }^{4}$ Faculty of Bioindustry, Tokyo University of Agriculture, 196 Yasaka, Abashiri, Hokkaido 099-2493, Japan
}

ABSTRACT: We analyzed radiocesium $\left({ }^{134} \mathrm{Cs}\right.$ and $\left.{ }^{137} \mathrm{Cs}\right)$ levels in the muscle tissue of several odontocetes and mysticetes stranded on the coast of Hokkaido (the northernmost island of Japan) in 2011 and 2012, following the Fukushima Dai-ichi Nuclear Power Plant (FDNPP) accident in March 2011. Since most of the radiocesium from the FDNPP was released into the western North Pacific Ocean and carried eastward from the Japan coast, there was little radiocesium contamination in the seawater around Hokkaido. Hokkaido is surrounded by the North Pacific Ocean, the Japan Sea, and the Okhotsk Sea, but radiocesium was predominantly detected in the cetaceans stranded along the North Pacific coast between June and October 2011. Among the stranded cetaceans, which included the Pacific white-sided dolphin, harbour porpoise and Dall's porpoise (odontocetes) as well as the common minke whale and humpback whale (mysticetes), the highest level of contamination was found in a common minke whale. The radiocesium contamination of these cetaceans suggests that they moved seasonally from the south of Hokkaido, particularly through the contaminated area of the western North Pacific Ocean. The radiocesium levels in the tissues of these animals is likely a result of the contamination level of the seawater along their travel route, rather than their trophic level, because of the sudden changes in radiocesium transport and diffusion in seawater that occurred in 2011.

KEY WORDS: ${ }^{134} \mathrm{Cs} \cdot{ }^{137} \mathrm{Cs} \cdot$ Lagenorhynchus obliquidens · Phocoena phocoena · Phocoenoides dalli . Balaenoptera acutorostrata · Megaptera novaeangliae

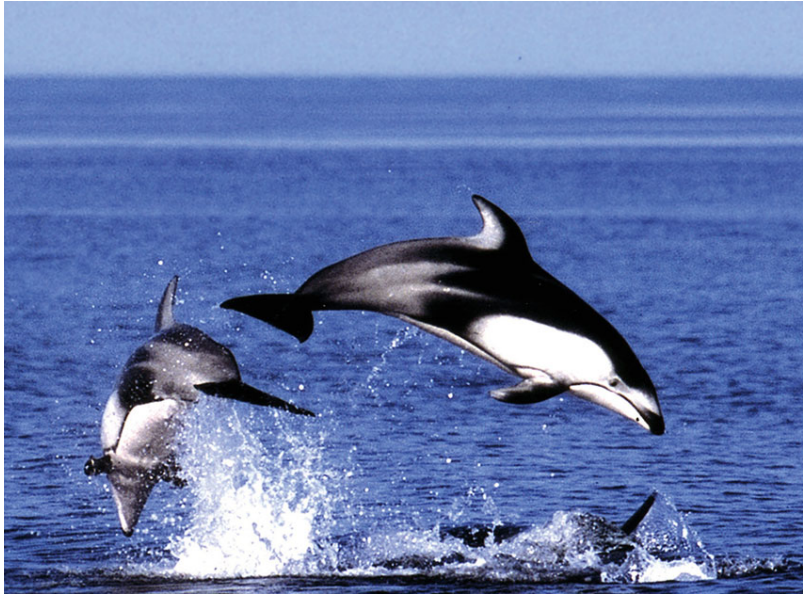

${ }^{137}$ Cs contamination in Pacific white-side dolphins suggests they had travelled from the contaminated waters near the Fukushima nuclear power plant.

Photo: Kotoe Sasamori

\section{INTRODUCTION}

On 11 March 2011, a massive earthquake occurred off Miyagi Prefecture, Japan. The earthquake and associated tsunami disrupted the operation of the Fukushima Dai-ichi Nuclear Power Plant (FDNPP), which resulted in the widespread release of large amounts of radiocesium $\left({ }^{134} \mathrm{Cs}\right.$ and $\left.{ }^{137} \mathrm{Cs}\right)$ as well as other radionuclides into the atmosphere and over an extensive area of ocean off eastern Japan. The estimated amount of ${ }^{137} \mathrm{Cs}$ emitted from the FDNPP was 
15 PBq (Honda et al. 2012), which is about one-sixth the amount emitted at the time of the Chernobyl nuclear power accident (about 85 PBq) (WHO 1989).

A large proportion of these radionuclides was transported and diffused eastward by the Kuroshio Current (Buesseler et al. 2011, Honda et al. 2012) (Fig. 1). In order to evaluate the contamination and transport processes of ${ }^{134} \mathrm{Cs}$ and ${ }^{137} \mathrm{Cs}$ in the marine environment, concentrations in seawater samples have been extensively analyzed in the vicinity of the FDNPP and over a large area of the western North Pacific Ocean. Before the FDNPP accident, ${ }^{137}$ Cs concentrations in seawater samples from the western North Pacific Ocean were about 1 to $2 \mathrm{mBq}{ }^{-1}$ and there were only trace amounts of ${ }^{134} \mathrm{Cs}$ (Oikawa et al. 2013). One month after the accident (14 April to 5 May 2011), ${ }^{137}$ Cs concentrations in samples collected from a wide area of the western North Pacific Ocean quickly increased between several fold and 2 orders of magnitude (5 to $284 \mathrm{mBq} \mathrm{l}^{-1}$ ), not only as an aerosol via the atmosphere but also due to the diffusion and advection of seawater (Honda et al. 2012).

${ }^{134} \mathrm{Cs}$ and ${ }^{137} \mathrm{Cs}$ contamination of epipelagic fish (sardine and Japanese anchovy) caught off the Kashima-Boso area (south of FDNPP; Fig. 1) suddenly increased, reaching a maximum level $\left({ }^{137} \mathrm{Cs}\right.$ : $31 \mathrm{~Bq}$ $\mathrm{kg}^{-1}$ ) between June and August 2011, and rapidly decreasing thereafter (Takagi et al. 2014). Similar changes in radiocesium were also found in the seawater collected in the Kashima-Boso area, where the peak ${ }^{137} \mathrm{Cs}$ level was about $4 \mathrm{~Bq} \mathrm{l}^{-1}$ (Aoyama et al. 2012). Although the reasons for the delay in these peaks are not yet understood, the changes in the radiocesium contamination of the seawater and fish could be closely related. A similar delayed peak for ${ }^{137}$ Cs was found between June and August 2011 in seawater off the northern Sanriku coast and the Pacific side of the Shimokita Peninsula, which are both to the north of the FDNPP (Fig. 1), but the delayed peak was very small: the highest ${ }^{137} \mathrm{Cs}$ concentration detected there was only 0.05 Bq ${ }^{-1}$ (Kofuji \& Inoue 2013).

Compared with the vicinity around the FDNPP and to the east of Japan, there was little radionuclide contamination in the seawater off northern (Hokkaido) and western Japan (Inoue et al. 2012a,b,c). The increases in ${ }^{134} \mathrm{Cs}$ and ${ }^{137} \mathrm{Cs}$ concentrations in seawater collected from the Japan Sea (the area of the Tsushima Current; Fig. 1) were smaller than those seen in the western North Pacific Ocean (Inoue et al. 2012c). Similarly, radiocesium concentrations in the Tsugaru Warm Current water (a branch of the Tsushima Current) flowing out of the Japan Sea through the Tsugaru Strait, were markedly lower than those in the western North Pacific Ocean (Inoue et al. 2012c). It is thought that the Tsugaru and Oyashio Currents

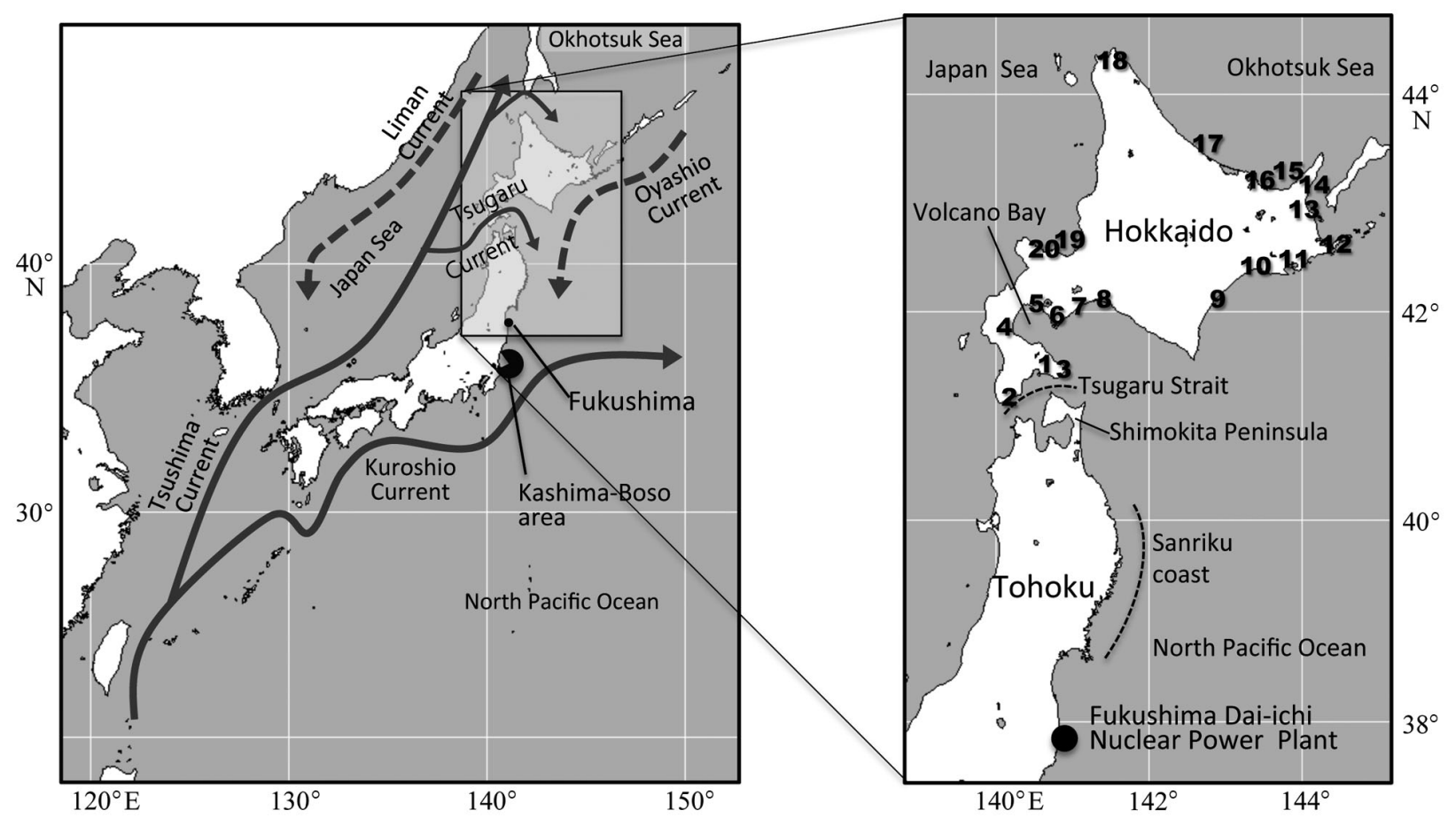

Fig. 1. Hokkaido and Tohoku areas of Japan; numbers in expanded insert correspond to locations of stranded animals provided in Table 1 
could have inhibited the transport and diffusion of ${ }^{134} \mathrm{Cs}$ and ${ }^{137} \mathrm{Cs}$ to the coastal areas off Hokkaido (Inoue et al. 2012c, Honda et al. 2012) (Fig. 1).

The long-lived artificial radionuclide ${ }^{137} \mathrm{Cs}$ (halflife: $30.2 \mathrm{yr}$ ) is of great interest and importance as an indicator of radionuclide pollution in the marine environment, as ${ }^{137} \mathrm{Cs}$ tends to concentrate through the food chain in the marine ecosystem (Kasamatsu \& Ishikawa 1997, Kasamatsu et al. 1999). Marine mammals are generally located at the top of the marine food chain and have been shown to accumulate ${ }^{137} \mathrm{Cs}$ in the muscle rather than in the liver or kidney (Calmet et al. 1991). In contrast, levels of ${ }^{134} \mathrm{Cs}$ are generally below detection in marine biota because of its shorter half-life (2.06 yr). In 1986, the Chernobyl nuclear power station accident resulted in radionuclide contamination, not only of the Black Sea and Baltic Sea, but of oceans worldwide. Kasamatsu \& Ishikawa (1997) analyzed the ${ }^{137} \mathrm{Cs}$ concentrations in 30 species of marine fauna collected from the coastal areas surrounding Japan using dried and ashed samples, and reported increases in ${ }^{137} \mathrm{Cs}$ accumulation with increased trophic level, with a biomagnification factor $\left({ }^{137} \mathrm{Cs}\right.$ in predator $/{ }^{137} \mathrm{Cs}$ in prey) of 2.0. Using the same methodology, Kasamatsu et al. (1999) analyzed the ${ }^{137} \mathrm{Cs}$ concentrations in 2 Dall's porpoises Phocoenoides dalli and seawater samples collected from the coastal waters off Japan in 1996, and reported that the ${ }^{137} \mathrm{Cs}$ concentrations in the Dall's porpoises were 0.153 and $0.234 \mathrm{~Bq} \mathrm{~kg}^{-1}$, with ${ }^{137} \mathrm{Cs}$ concentration factors $\left({ }^{137} \mathrm{Cs}\right.$ in animal $/{ }^{137} \mathrm{Cs}$ in seawater) of 59 and 90, respectively. Yoshitome et al. (2003) analyzed ${ }^{137} \mathrm{Cs}$ concentrations in northern fur seals Callorhinus ursinus $(\mathrm{n}=5)$ and Dall's porpoises $(\mathrm{n}=$ 5) collected from off the coast of Sanriku, Japan between 1997 and 2000 using the dried/ashed sample methodology and reported concentrations of $0.21 \pm 0.09 \mathrm{~Bq} \mathrm{~kg}^{-1}$ in the northern fur seals and $0.17 \pm 0.05 \mathrm{~Bq} \mathrm{~kg}^{-1}$ in the Dall's porpoises. However, the ${ }^{134} \mathrm{Cs}$ and ${ }^{137} \mathrm{Cs}$ concentrations in marine mammals inhabiting the coastal waters off Japan following the FDNPP accident have not yet been reported.

Many cetaceans, such as the Dall's porpoise, Pacific white-sided dolphin Lagenorhynchus obliquidens and common minke whale Balaenoptera acutorostrata, inhabit the coastal waters off Japan, and generally move from south to north in spring and vice versa in autumn. Although seasonal travel routes have been estimated (Amano 1998, Tsutsui et al. 2001, Hayano et al. 2003, Amano \& Hayano 2007, Wade et al. 2010, see Fig. 4), detailed travel routes remain uncertain, despite the development of a number of research techniques. For instance, Pacific white-sided dolphins are observed in the mouth of Volcano Bay, Hokkaido, between late May and the end of August every year, but there is no direct evidence to explain the route that this species takes to arrive in that area (Tsutsui et al. 2001, Amano \& Hayano 2007).

Here, we report the analytical data obtained for ${ }^{134} \mathrm{Cs}$ and ${ }^{137} \mathrm{Cs}$ concentrations, along with the naturally occurring radionuclide potassium-40 $\left({ }^{40} \mathrm{~K}\right)$, in odontocetes and mysticetes stranded on the coast of Hokkaido (the northernmost island of Japan) after the FDNPP accident. We also propose possible migratory routes taken by those cetaceans based on the accumulation of radiocesium in their tissues.

\section{MATERIALS AND METHODS}

\section{Cetacean tissue samples}

We obtained muscle tissue samples from cetaceans stranded on the coast of Hokkaido, Japan between April 2011 and September 2012 from the Stranding Network Hokkaido (SNH). The odontocete species from which muscle samples were obtained comprised the Pacific white-sided dolphin, harbour porpoise Phocoena phocoena, Dall's porpoise, Baird's beaked whale Berardius bairdii, Stejneger's beaked whale Mesoplodon stejnegeri, Hubbs' beaked whale Mesoplodon carlhubbsi, pygmy sperm whale Kogia breviceps, Cuvier's beaked whale Ziphius cavirostris and killer whale Orcinus orca. Samples were also obtained from mysticete species including the common minke whale and humpback whale Megaptera novaeangliae. We also obtained muscle samples from a Pacific white-sided dolphin and a Dall's porpoise that were incidentally caught in salmon drift nets operated as part of a scientific survey by training vessel 'Oshoro-maru', about $1000 \mathrm{~km}$ offshore from Hokkaido at $39^{\circ} \mathrm{N}, 155^{\circ} \mathrm{E}$ and $41^{\circ} \mathrm{N}, 155^{\circ} \mathrm{E}$, respectively (see Fig. 4A,B).

We purchased 2 red meat samples, which originated from a Dall's porpoise and a Baird's beaked whale caught in the North Pacific Ocean, from retail outlets in Miyagi Prefecture (Tohoku area) in 2003 and 2004 before the FDNPP accident. We also purchased 2 red meat samples, originating from common minke whales caught off Kushiro by the Japanese Research Whaling Program, from retail outlets in June and October 2011, after the FDNPP accident.

See Table 1 for a summary of the background information and analytical results for all cetacean samples analyzed. The samples of the small cetaceans were stored at $-20^{\circ} \mathrm{C}$ until analysis. 


\section{Chemical analyses}

Precisely weighed samples were packed into $100 \mathrm{ml}$ polystyrene containers (U-8 containers, Asone Co.). The radioactivity of ${ }^{137} \mathrm{Cs},{ }^{134} \mathrm{Cs}$ and ${ }^{40} \mathrm{~K}$ in the samples was measured for $50000 \mathrm{~s}$ by $\gamma$-ray spectrometry using an ORTED system (Ortec Industries). Gamma-ray peaks of 661, 604.7, and $1461 \mathrm{keV}$ were used to determine ${ }^{137} \mathrm{Cs},{ }^{134} \mathrm{Cs}$ and ${ }^{40} \mathrm{~K}$, respectively, with detection limits of approximately $1.0 \mathrm{~Bq} \mathrm{~kg}{ }^{-1}$. In some cases, dried samples (treated at $\mathrm{ca} .50^{\circ} \mathrm{C}$ for $12 \mathrm{~h}$ ) were measured. In such cases, the nuclide detection limits were approximately $0.3 \mathrm{~Bq} \mathrm{~kg}^{-1}$. As the half-life of ${ }^{134} \mathrm{Cs}$ is relatively short (2.06 yr), the measured ${ }^{134} \mathrm{Cs}$ values were decay-corrected using the date of stranding to estimate the ${ }^{134} \mathrm{Cs}$ concentration at the time of stranding.

\section{Statistical analyses}

Data were analyzed by Pearson's correlation coefficient test, using the Statcel 2 program; results were considered significant at $\mathrm{p}<0.05$. Data are shown as mean $\pm \mathrm{SD}$

\section{RESULTS}

\section{Area and period of ${ }^{134} \mathrm{Cs}$ and ${ }^{137} \mathrm{Cs}$ contamination in stranded cetaceans}

Among the 47 cetacean stranded on the coast of Hokkaido, radiocesium contamination (>1.0 $\mathrm{Bq} \mathrm{kg}^{-1}$ ) was detected in 19 animals, including 3 mysticetes (Table 1). As shown in Fig. 1, Hokkaido is surrounded by the North Pacific Ocean, the Japan Sea and the Okhotsk Sea. Most of the cetaceans contaminated with ${ }^{134} \mathrm{Cs}$ and ${ }^{137} \mathrm{Cs}$ or with ${ }^{137} \mathrm{Cs}$ alone were stranded along the North Pacific Ocean coast, in and around Volcano Bay (southwest area; locations 1 to 8 in Fig. 1), and in eastern Hokkaido (locations 9 to 14). In contrast, ${ }^{134} \mathrm{Cs}$ and ${ }^{137} \mathrm{Cs}$ contamination in the cetaceans stranded along the Okhotsk Sea coast (locations 15, 16 and 17) and the Japan Sea coast (locations 18, 19 and 20) was below the detection limits in all animals except for one harbour porpoise (ID\# SNH12001, location 19).

Most of the cetaceans that were contaminated with ${ }^{137} \mathrm{Cs}$ were stranded between June and October 2011, whereas after January 2012, ${ }^{137}$ Cs levels in stranded cetaceans were below detection limits (ex- cept for one sample from a common minke whale: SNH12020) (Fig. 2).

The ratio of ${ }^{134} \mathrm{Cs}$ to ${ }^{137} \mathrm{Cs}$ ranged from 0.65 to 0.90 $(\mathrm{n}=18)$, with the ratio of the regression line since 11 March 2011 being approx. 1 (Fig. 3). The average level of ${ }^{40} \mathrm{~K}$ in the cetaceans was $105 \pm 17 \mathrm{~Bq} \mathrm{~kg}^{-1}$ wet weight (Table $1 ; \mathrm{n}=47$ ), irrespective of the date of stranding. The correlation between the ${ }^{40} \mathrm{~K}$ and ${ }^{137} \mathrm{Cs}$ concentrations was not significant $(r=0.342$, $p>0.05$, $\mathrm{n}=20$ ) and the ratio of ${ }^{40} \mathrm{~K}$ to ${ }^{137} \mathrm{Cs}$ concentration was $0.061 \pm 0.052$.

\section{${ }^{134} \mathrm{Cs}$ and ${ }^{137} \mathrm{Cs}$ contamination in odontocetes}

Seven Pacific white-sided dolphins that stranded between July and September 2011 on the coast in and around Volcano Bay (southwest area; locations 1, 5, 6, 7 and 8) and on the east coast of Hokkaido (location 13) were contaminated with ${ }^{134} \mathrm{Cs}$ and ${ }^{137} \mathrm{Cs}$. These radionuclides were also detected in the Pacific white-sided dolphin taken by ship on 20 May 2011 in the North Pacific Ocean at $39^{\circ}$ N, $155^{\circ}$ E (SNH11012) (Fig. 4A). However, the ${ }^{134} \mathrm{Cs}$ and ${ }^{137} \mathrm{Cs}$ levels in 4 Pacific white-sided dolphins stranded in 2012 were below detection limits. Similarly, ${ }^{134} \mathrm{Cs}$ and ${ }^{137} \mathrm{Cs}$ contamination was detected in 4 harbour porpoises stranded on the southwest (locations 1, 6 and 9) and east coast (location 14) of Hokkaido between June and September in 2011, whereas contamination levels in harbour porpoises stranded in 2012 were below the detection limits, except for SNH12001.

${ }^{137} \mathrm{Cs}$ contamination was detected in 2 Dall's porpoises stranded on the southwest (SNH11013; location 2, May 2011) and east (SNH11037; location 13, August 2011) coast of Hokkaido, but the ${ }^{134} \mathrm{Cs}$ concentration in SNH11013 was below detection limits. As with the Pacific white-sided dolphins and harbour porpoises (except for SNH12001), ${ }^{134} \mathrm{Cs}$ and ${ }^{137} \mathrm{Cs}$ contamination in the Dall's porpoise stranded in 2012 was below the detection limit. ${ }^{137} \mathrm{Cs}$ was detected in the Dall's porpoise taken by ship on 19 May 2011 in the North Pacific Ocean at $41^{\circ} \mathrm{N}, 155^{\circ} \mathrm{E}$ (SNH11011) (Fig. 4B); the ${ }^{134} \mathrm{Cs}$ concentration in that sample was below the detection limit.

${ }^{137} \mathrm{Cs}$ contamination was detected in 2 pygmy sperm whales stranded on the Pacific Ocean coast in September 2011 (SNH11043; location 8) and May 2012 (SNH12011; location 9), whereas the ${ }^{134}$ Cs concentration was below the detection limit. In contrast, both the ${ }^{134} \mathrm{Cs}$ and ${ }^{137} \mathrm{Cs}$ concentrations were below the detection limit in a Baird's beaked whale (April 2011, location 18), a Stejneger's beaked whale (April 
Table 1. Radionuclides ${ }^{134} \mathrm{Cs},{ }^{137} \mathrm{Cs}$ and ${ }^{40} \mathrm{~K}$ in muscle tissues of cetaceans stranded on the coast of Hokkaido, in northern Japan, and ${ }^{*}$ samples from 2 species caught $1000 \mathrm{~km}$ offshore. Locations are numbered according to the positions shown in Fig. 1 ; gender: $\mathrm{M}=$ male, $\mathrm{F}=$ female, U = unknown; SNHID no.: Stranding Network Hokkaido identification number; ND: not detected

\begin{tabular}{|c|c|c|c|c|c|c|c|c|}
\hline Species & SNH ID no. & Location & $\begin{array}{l}\text { Date of finding } \\
\text { (dd/mm/yyyy) }\end{array}$ & $\begin{array}{l}\text { Body length }(\mathrm{m}) \\
\text { and gender }\end{array}$ & $\begin{array}{c}{ }^{134} \mathrm{Cs} \\
\left(\mathrm{Bq} \mathrm{kg}{ }^{-1}\right)\end{array}$ & $\begin{array}{c}\left.{ }^{137} \mathrm{Cs}^{-1}\right) \\
\left(\mathrm{Bq} \mathrm{kg}{ }^{-1}\right)\end{array}$ & $\begin{array}{c}\text { Ratio } \\
\left({ }^{134} \mathrm{Cs} /{ }^{137} \mathrm{Cs}\right)\end{array}$ & $\begin{array}{c}{ }^{40} \mathrm{~K} \\
\left(\mathrm{~Bq} \mathrm{~kg}{ }^{-1}\right)\end{array}$ \\
\hline \multirow{12}{*}{$\begin{array}{l}\text { Pacific white-sided } \\
\text { dolphin }\end{array}$} & SNH11012 & ${ }^{*} 39^{\circ} \mathrm{N}, 155^{\circ} \mathrm{E}$ & $20 / 05 / 2011$ & $1.43(\mathrm{M})$ & 8.32 & 9.84 & 0.85 & 102 \\
\hline & SNH11027 & Muroran 6 & 06/07/2011 & $2.19(\mathrm{M})$ & 8.13 & 8.27 & 0.98 & 75 \\
\hline & SNH11028 & Abuta 5 & 09/07/2011 & $2.02(\mathrm{~F})$ & 8.02 & 8.42 & 0.95 & 89 \\
\hline & SNH11029 & Noboribetsu 7 & 10/07/2011 & $2.15(\mathrm{M})$ & 10.99 & 12.2 & 0.9 & 105 \\
\hline & SNH11034 & Shibetsu 13 & $31 / 07 / 2011$ & $2.07(\mathrm{U})$ & 2.4 & 2.99 & 0.8 & 63 \\
\hline & SNH11036 & Hakodate 1 & 04/08/2011 & $1.43(\mathrm{U})$ & 4.34 & 5.16 & 0.84 & 100 \\
\hline & SNH11038 & Noboribetsu 7 & 10/08/2011 & $2.19(\mathrm{M})$ & 6.24 & 7.69 & 0.81 & 83 \\
\hline & SNH11042 & Tomakomai 8 & 07/09/2011 & $2.20(\mathrm{M})$ & 5.71 & 6.96 & 0.82 & 93 \\
\hline & SHN12026 & Hakodate 1 & $15 / 06 / 2012$ & $(\mathrm{~F})$ & ND & ND & - & 104 \\
\hline & SNH12032 & Tomakomai 8 & $15 / 07 / 2012$ & $2.16(\mathrm{M})$ & ND & ND & - & 116 \\
\hline & SNH12036 & Noboribetsu 7 & $30 / 07 / 2012$ & $2.18(\mathrm{M})$ & ND & ND & - & 109 \\
\hline & SNH12037 & Noboribetsu 7 & $31 / 07 / 2012$ & $2.19(\mathrm{~F})$ & ND & ND & - & 110 \\
\hline \multirow[t]{11}{*}{ Harbour porpoise } & SNH11018 & Hakodate 1 & 18/06/2011 & $1.74(\mathrm{~F})$ & 1.53 & 1.7 & 0.9 & 100 \\
\hline & SNH11019 & Rausu 14 & 19/06/2011 & $1.23(\mathrm{M})$ & ND & ND & - & 129 \\
\hline & SNH11032 & Rausu 14 & $21 / 07 / 2011$ & $1.56(\mathrm{M})$ & 3.62 & 4 & 0.91 & 123 \\
\hline & SNH11039 & Muroran 6 & 10/08/2011 & $1.19(\mathrm{M})$ & 8.05 & 8.84 & 0.91 & 80 \\
\hline & SNH11041 & Toyokoro 9 & 03/09/2011 & $1.29(\mathrm{~F})$ & 3.62 & 5 & 0.72 & 116 \\
\hline & SNH12001 & Ishikari 19 & $12 / 01 / 2012$ & $1.23(\mathrm{~F})$ & ND & 1.1 & - & 110 \\
\hline & SNH12003 & Ishikari 19 & $07 / 02 / 2012$ & 1.55 (U) & ND & ND & - & 115 \\
\hline & SNH12004 & Ishikari 19 & $11 / 02 / 2012$ & $1.55(\mathrm{M})$ & ND & ND & - & 118 \\
\hline & SNH12006 & Noboribetsu 7 & $27 / 03 / 2012$ & $1.31(\mathrm{~F})$ & ND & ND & - & 93 \\
\hline & SNH12022 & Rausu 14 & $11 / 06 / 2012$ & $1.30(\mathrm{~F})$ & ND & ND & - & 148 \\
\hline & SNH12025 & Rausu 14 & $13 / 06 / 2012$ & $1.21(\mathrm{~F})$ & ND & ND & - & 119 \\
\hline \multirow[t]{11}{*}{ Dall's porpoise } & SNH11011 & ${ }^{*} 41^{\circ} \mathrm{N}, 155^{\circ} \mathrm{E}$ & 19/05/2011 & $1.75(\mathrm{~F})$ & ND & 1.06 & - & 112 \\
\hline & SNH11013 & Matumae 2 & $24 / 05 / 2011$ & 1.57 (F) & ND & 2.04 & - & 117 \\
\hline & SNH11017 & Rausu 14 & 11/06/2011 & 1.97 (M) & ND & $\mathrm{ND}$ & - & 113 \\
\hline & SNH11021-2 & Rausu 14 & $27 / 06 / 2011$ & $1.85(\mathrm{~F})$ & ND & ND & - & 110 \\
\hline & SNH11037 & Shibetsu 13 & 09/08/2011 & (M) & 1.72 & 2.51 & 0.69 & 113 \\
\hline & SNH12023 & Otaru 20 & $11 / 06 / 2012$ & $2.04 \mathrm{M})$ & ND & ND & - & 114 \\
\hline & SNH12024-1 & Rausu 14 & $13 / 06 / 2012$ & $1.86(\mathrm{~F})$ & ND & ND & - & 111 \\
\hline & SNH12024-2 & Rausu 14 & 13/06/2012 & $1.92(\mathrm{~F})$ & ND & ND & - & 122 \\
\hline & SNH12027 & Rausu 14 & $23 / 06 / 2012$ & $1.95(\mathrm{M})$ & ND & ND & - & 115 \\
\hline & SNH12029 & Rausu 14 & $26 / 06 / 2012$ & $2.03(\mathrm{M})$ & ND & ND & - & 114 \\
\hline & SNH12031 & Rausu 14 & 09/07/2012 & $1.89(\mathrm{M})$ & ND & ND & - & 119 \\
\hline Baird's beaked whale & SNH11006 & Wakkanai 18 & 08/04/2011 & $9.83(\mathrm{~F})$ & ND & ND & - & 92 \\
\hline Stejneger's beaked whale & SNH11007 & Ishikari 19 & $07 / 04 / 2011$ & $4.53(\mathrm{M})$ & ND & ND & - & 85 \\
\hline Hubbs' beaked whale & SNH11016 & Yakumo 4 & $30 / 05 / 2011$ & $5.10(\mathrm{M})$ & ND & ND & - & 87 \\
\hline \multirow[t]{2}{*}{ Pygmy sperm whale } & SNH11043 & Tomakomai 8 & $21 / 09 / 2011$ & $2.23(\mathrm{~F})$ & 2.41 & 3.38 & 0.71 & 98 \\
\hline & SNH12011 & Toyokoro 9 & $10 / 05 / 2012$ & $2.10(\mathrm{~F})$ & ND & 1.52 & - & 137 \\
\hline Cuvier's beaked whale & SNH12010 & Muroran 6 & $01 / 05 / 2012$ & $5.48(\mathrm{M})$ & ND & ND & - & 91 \\
\hline Killer whale & SNH12015 & Rausu 14 & $19 / 05 / 2012$ & $3.84(\mathrm{~F})$ & ND & ND & - & 116 \\
\hline \multirow[t]{6}{*}{ Common minke whale } & SNH11047 & Monbetsu 17 & 09/11/2011 & ca 4 (U) & ND & ND & - & 80 \\
\hline & SNH11048 & Abashiri 16 & $10 / 11 / 2011$ & $4.66(\mathrm{M})$ & ND & ND & - & 87 \\
\hline & SNH11049 & Minamikayabe 3 & 3 24/11/2011 & $6.24(\mathrm{M})$ & 14.39 & 19.88 & 0.72 & 90 \\
\hline & SNH12020 & Tomakomai 8 & $28 / 05 / 2012$ & $5.22(\mathrm{~F})$ & 1.9 & 2.86 & 0.77 & 116 \\
\hline & SNH12028 & Nemuro 12 & $25 / 06 / 2012$ & ca. $5(\mathrm{~F})$ & ND & ND & - & 113 \\
\hline & SNH12045 & Shari 15 & 03/09/2012 & ca. 7 (U) & ND & ND & - & 104 \\
\hline \multirow[t]{2}{*}{ Humpback whale } & SNH11030 & Hamanaka 11 & 15/07/2011 & $7.58(\mathrm{M})$ & 1.95 & 2.63 & 0.65 & 75 \\
\hline & SNH12047 & Noboribetdu 7 & $27 / 09 / 2012$ & $8.65(\mathrm{M})$ & ND & ND & - & 98 \\
\hline
\end{tabular}

2011, location 19), a Hubbs' beaked whale (May 2011, location 4), a Culvier's beaked whale (May 2011, location 6) and a killer whale (May 2012, location 14) stranded in 2011 and 2012 along the coast of Hokkaido.

\section{${ }^{134} \mathrm{Cs}$ and ${ }^{137} \mathrm{Cs}$ contamination in mysticetes}

Among the contaminated cetaceans (Table 1, $\mathrm{n}=19$ ), the highest concentrations of ${ }^{134} \mathrm{Cs}$ and ${ }^{137} \mathrm{Cs}$ were detected in a common minke whale stranded along 


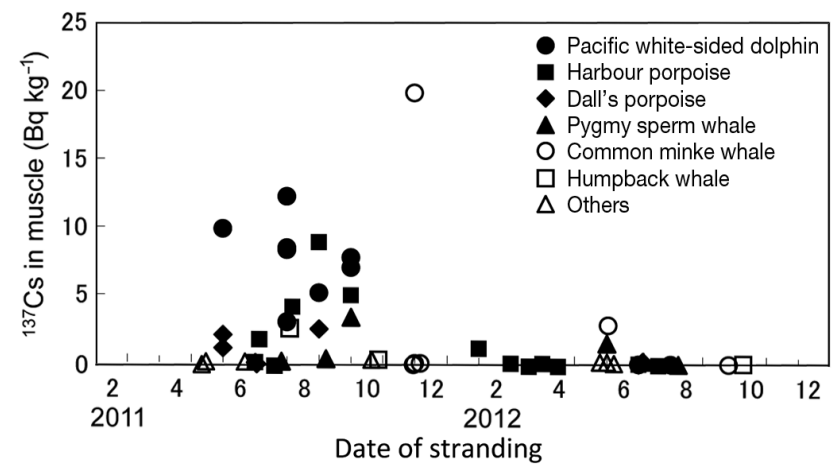

Fig. $2 .{ }^{137} \mathrm{Cs}$ activity in cetaceans stranded along the coast of Hokkaido in 2011 and 2012

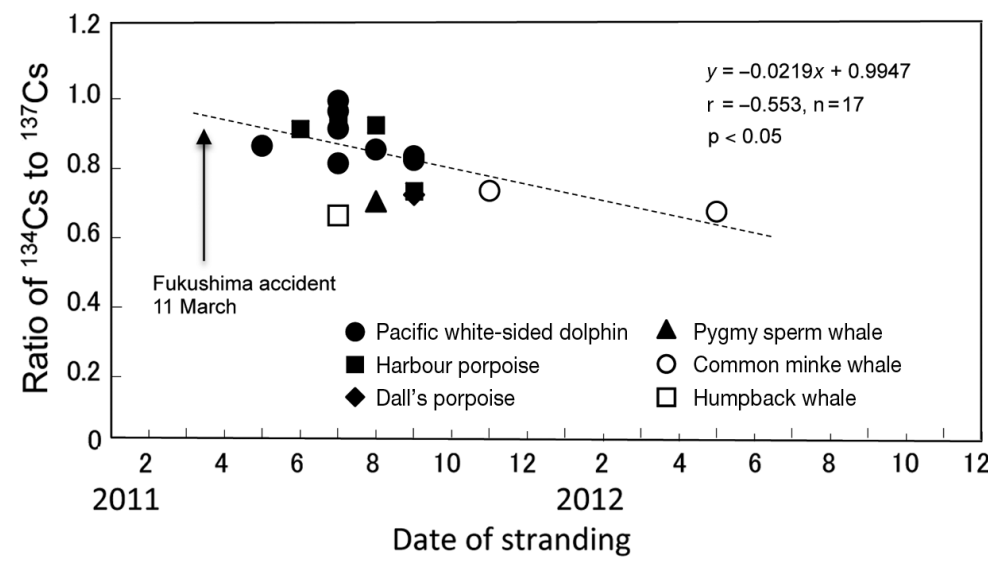

Fig. 3. Ratio of ${ }^{134} \mathrm{Cs}$ to ${ }^{137} \mathrm{Cs}$ in cetaceans stranded along the coast of Hokkaido in 2011 and 2012

the North Pacific Ocean coast of Hokkaido in November 2011 (SNH11049; location 3). ${ }^{134} \mathrm{Cs}$ and ${ }^{137} \mathrm{Cs}$ contamination was also detected in a common minke whale stranded in May 2012 along the North Pacific Ocean coast (SNH12020; location 8). In addition, ${ }^{137} \mathrm{Cs}$ contamination was found in 2 red meat samples from common minke whales caught off Kushiro (location 10) on the North Pacific Ocean side of Hokkaido (Fig. $4 \mathrm{C}_{i}{ }^{137} \mathrm{Cs}$ in the 2 samples was 1.05 and $2.87 \mathrm{~Bq} \mathrm{~kg}^{-1}$, respectively; data not shown).

${ }^{134} \mathrm{Cs}$ and ${ }^{137} \mathrm{Cs}$ contamination was detected in a humpback whale stranded along the North Pacific Ocean coast in July 2011 (SNH11030; location 11), whereas the levels of contamination in the same species stranded along the North Pacific Ocean coast in September 2012 (SNH12047; location 7) were below the detection limit.

\section{DISCUSSION}

\section{${ }^{134} \mathrm{Cs},{ }^{137} \mathrm{Cs},{ }^{40} \mathrm{~K}$ and ${ }^{137} \mathrm{Cs}$ concentration} factor in cetaceans before the accident

The ${ }^{137} \mathrm{Cs}$ levels in the muscle samples of 2 Dall's porpoises caught off Hamanaka on the North Pacific Ocean side of Hokkaido in 1966 were 0.153 and $0.234 \mathrm{~Bq} \mathrm{~kg}^{-1}$ (Kasamatsu et al. 1999), and those in Dall's porpoises and northern fur seals caught off Sanriku (North Pacific Ocean side) in 1997 and 2000 were $0.17 \pm 0.05 \mathrm{~Bq} \mathrm{~kg}^{-1}(\mathrm{n}=5)$ and $0.21 \pm 0.09 \mathrm{~Bq}$ $\mathrm{kg}^{-1}(\mathrm{n}=5)$, respectively (Yoshitome et al. 2003). In order to analyze these low levels of ${ }^{134} \mathrm{Cs}$ and ${ }^{137} \mathrm{Cs}$, those research groups used dried or ashed samples, but were still unable to determine the level of ${ }^{134} \mathrm{Cs}$.

No ${ }^{134} \mathrm{Cs}$ or ${ }^{137} \mathrm{Cs}$ contamination has been reported in fish, except for Pacific cod Gadus macrocephalus, caught off Hokkaido after the FDNPP accident (www. pref.hokkaido.lg.jp/sr/ske/ek/sakanamnt.htm), and only small increases in ${ }^{134} \mathrm{Cs}$ and ${ }^{137} \mathrm{Cs}$ were observed in seawater collected from the coastal waters off Hokkaido (Inoue et al. 2012a,b). The concentration

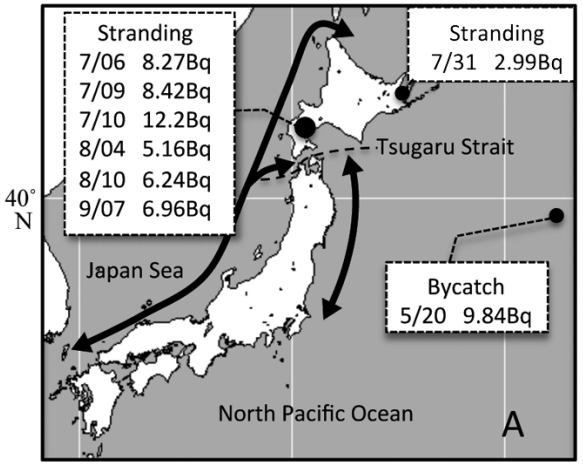

$130^{\circ} \mathrm{E}$
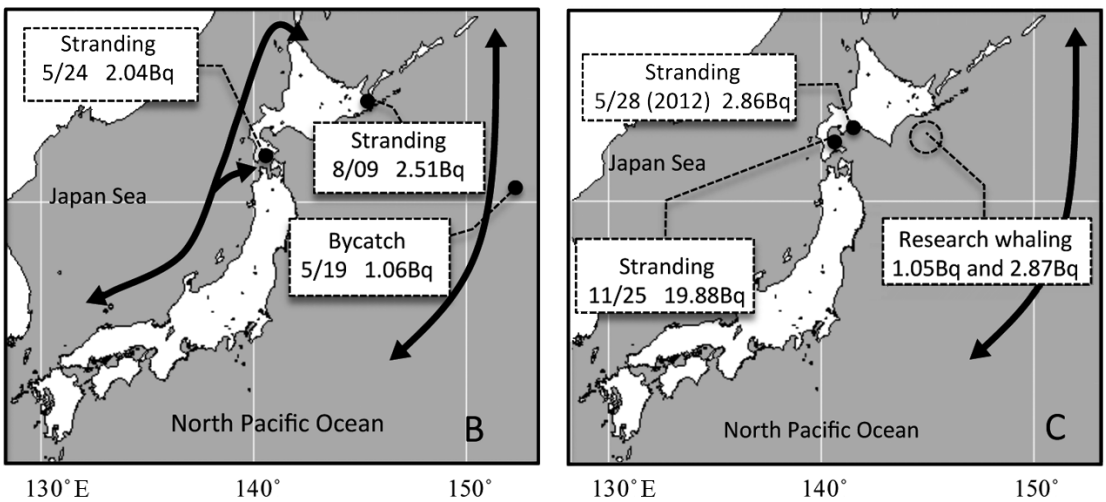

Fig. 4. Putative travel routes of (A) Pacific white sided dolphin, (B) Dall's porpoise (dalli-type color morph) and (C) common minke whale (O-type) around Japan (solid lines with arrows), and ${ }^{137} \mathrm{Cs}$ activity in those cetaceans after the Fukushima accident 
factor (animal/seawater) of ${ }^{137} \mathrm{Cs}$ was estimated to be 60 to 90 in Dall's porpoises (Kasamatsu et al. 1999), $186 \pm 141$ for marine mammals in general (Yoshitome et al. 2003), and 100 to 400 in harbour porpoises (Berrow et al. 1998). Given a typical concentration factor of 100 and a ${ }^{137} \mathrm{Cs}$ concentration of $2 \mathrm{mBq} \mathrm{kg}{ }^{-1}$ in seawater (Oikawa et al. 2013), the ${ }^{137} \mathrm{Cs}$ concentration in Dall's porpoises stranded along the coast of Hokkaido would be expected to be about $0.2 \mathrm{~Bq} \mathrm{~kg}^{-1}$. However, this calculated value is markedly lower than the analytical value obtained for the stranded Dall's porpoise we analyzed (Table 1). These results suggest that the Dall's porpoises were contaminated with ${ }^{134} \mathrm{Cs}$ and ${ }^{137} \mathrm{Cs}$ in the coastal waters off Sanriku and the Shimokita Peninsula before stranding on the coast of Hokkaido.

The average level of ${ }^{40} \mathrm{~K}$, a naturally occurring radionuclide, in the stranded cetaceans (Table 1) was in accordance with that in marine mammals inhabiting the coastal waters off the British Isles (Berrow et al. 1998, Watson et al. 1999). Thus, the ${ }^{40} \mathrm{~K}$ concentration in the cetacean muscle may be constant at about $100 \mathrm{~Bq} \mathrm{~kg}{ }^{-1}$. According to the literature (Kasamatsu et al. 1999), an increase in $K$ concentration in seawater increases the efflux of ${ }^{137} \mathrm{Cs}$ from fish, but it does not affect the influx of ${ }^{137} \mathrm{Cs}$. In the present study, however, the ratio of ${ }^{40} \mathrm{~K}$ to ${ }^{137} \mathrm{Cs}$ concentration in the cetaceans was almost constant $(0.061 \pm 0.052)$.

\section{${ }^{134} \mathrm{Cs}$ and ${ }^{137} \mathrm{Cs}$ in stranded cetaceans and small fish after the accident}

Similar to the cetaceans stranded along the coast of Hokkaido (Fig. 2), ${ }^{134} \mathrm{Cs}$ and ${ }^{137} \mathrm{Cs}$ contamination in small fish caught off the Kashima-Boso region (south of the FDNPP, see Fig. 1) suddenly increased, reaching a maximum value (31 $\mathrm{Bq} \mathrm{kg}^{-1}$ ) between June and August 2011, and rapidly decreasing thereafter (Takagi et al. 2014). The biological half-life of ${ }^{137} \mathrm{Cs}$ in many fish species ranges from 10 to 17 yr $(13 \pm 3$ yr) (Kasamatsu \& Ishikawa 1997, Kasamatsu \& Inatomi 1998). The rapid decrease in ${ }^{137} \mathrm{Cs}$ found in the small cetaceans (Fig. 2) and small fish (Takagi et al. 2014) cannot be explained by the biological half-life, as the change in ${ }^{137} \mathrm{Cs}$ in the seawater near the FDNPP was rapid and did not reach a steady state of influx and efflux in 2011 (Kofuji \& Inoue 2013, Takagi et al. 2014).

According to the literature (Kasamatsu \& Ishikawa 1997, Kasamatsu et al. 1999), ${ }^{134} \mathrm{Cs}$ and ${ }^{137} \mathrm{Cs}$ accumulate in marine biota via the food web in a trophic level-dependent manner, thus their concentrations would be expected to be higher in odontocetes than in mysticetes. However, the highest levels of radiocesium contamination were found in a mysticete (a common minke whale; Table 1), and an extremely high level of ${ }^{137} \mathrm{Cs}$ was found in small fish (Takagi et al. 2014). Thus, contamination levels in these species may depend on the level of contamination in seawater rather than on trophic level, as changes in radiocesium levels in the environment did not reach a steady state of influx and efflux in 2011.

The ratio of ${ }^{134} \mathrm{Cs}$ to ${ }^{137} \mathrm{Cs}$ in cetacean samples at the time of the FDNPP accident (11 March 2011), as estimated from the regression line, was about 1 (Fig. 3). This suggests that the emissions of ${ }^{134} \mathrm{Cs}$ and ${ }^{137} \mathrm{Cs}$ from the FDNPP were equal, which is in agreement with seawater measurements in the area (Aoyama et al. 2012, Kofuji \& Inoue 2013). Before the FDNPP accident, the ${ }^{134} \mathrm{Cs}$ levels in marine biota and seawater were at trace levels (Kasamatsu \& Ishikawa 1997, Oikawa et al. 2013). The ${ }^{134}$ Cs levels detected in some animals following the FDNPP accident, which exceeded 1.0 Bq kg-1, provides direct evidence for the accumulation of not only ${ }^{137} \mathrm{Cs}$ but also ${ }^{134} \mathrm{Cs}$ emitted from the FDNPP.

\section{Estimated travel routes of stranded cetaceans}

Fig. 4A-C shows the putative travel routes for the Pacific white-sided dolphin, Dall's porpoise and common minke whale inhabiting the waters around Japan.

There are 2 possible travel routes that the Pacific white-sided dolphins could take into Volcano Bay: the first brings them via the Sanriku and Shimokita coasts (North Pacific Ocean route), while the second has them travel via the Tsugaru Strait from the Japan Sea (Japan Sea route) (Tsutsui et al. 2001, see Fig. 4A). Their contamination with ${ }^{134} \mathrm{Cs}$ and ${ }^{137} \mathrm{Cs}$ appears to provide direct evidence for seasonal movements via the North Pacific Ocean route.

Two consistent and well-defined color morphs, the dalli-type and the truei-type, have been identified among Dall's porpoises (Amano \& Hayano 2007). All Dall's porpoises stranded along the coast of Hokkaido and analyzed in this study were dalli-type. Two travel routes have been postulated for dalli-type Dall's porpoise (Fig. 4B): one is via the Pacific Ocean route and the other is via the Japan Sea route through the Tsugaru Strait. As with the Pacific whitesided dolphin, the contamination of dalli-type Dall's porpoises with ${ }^{137} \mathrm{Cs}$ suggests that they, too, seasonally move via the North Pacific Ocean route.

Common minke whales can be genetically categorized into 2 types: 'O-type' found primarily in the off- 
shore Pacific Ocean, and 'J-type' found primarily in the Japan Sea and nearshore waters along Japan's Pacific coast (Wade et al. 2010). The O-type minke whales are the primary target of the Japanese Scientific Whaling Program. Although we did not genetically identify the stranded minke whales, they may have been O-type, and as with the Pacific whitesided dolphin and Dall's porpoise, the minke whale may have traveled from the contaminated area of the western North Pacific Ocean (Fig. 4C). ${ }^{134} \mathrm{Cs}$ and ${ }^{137} \mathrm{Cs}$ contamination was detected in a Pacific white-sided dolphin (SNH11012) and Dall's porpoise (SNH11011) incidentally caught in May 2011 at locations near the postulated travel migratory route of the common minke whale (Fig. 4).

Although little is known about the migratory route of the harbour porpoise, the possible route runs via the Sanriku and Shimokita coasts. Interestingly, ${ }^{137} \mathrm{Cs}$ contamination was detected in the harbour porpoise stranded on the coast of the Japan Sea in January 2012 (SNH12001; location 19). Further study is necessary to clarify the travel route of the harbour porpoise.

There are 3 putative Baird's beaked whale populations around Hokkaido, Japan: those in the Japan Sea, the Okhotsk Sea, and the Pacific Ocean (Kishiro 2007, Endo et al. 2010). According to the area in which it was stranded and its low level of ${ }^{137} \mathrm{Cs}$ contamination (below the detection limit), the Baird's beaked whale in this study (SNH11006; location 18) may belong to either the Japan Sea or the Okhotsk Sea population.

Little is known about the ecology of the Stejneger's beaked whale, Hubb's beaked whale, pygmy sperm whales, Cuvier's beaked whale or killer whale off the coast of Hokkaido. However, the detection of ${ }^{137} \mathrm{Cs}$ in the pygmy sperm whales suggests that they had moved through the radiocesium-contaminated area of the North Pacific Ocean. In contrast, the low levels of ${ }^{134} \mathrm{Cs}$ and ${ }^{137} \mathrm{Cs}$ contamination (i.e. below detection limits) seems to rule out the possibility that the other whales had traveled through the radiocesiumcontaminated area prior to stranding.

\section{CONCLUSIONS}

Radiocesium $\left({ }^{134} \mathrm{Cs}\right.$ and $\left.{ }^{137} \mathrm{Cs}\right)$ contamination was detected in the muscle tissue of several odontocete and mysticete species that were stranded around the coast of Hokkaido after the FDNPP accident in 2011. Contamination was found in species on the Pacific coast, but not in those stranded on the Japan Sea or
Okhotsk Sea coasts, between June and October 2011, suggesting that those cetaceans had travelled through the radiocesium contaminated area of western North Pacific Ocean. The degree of contamination in the animals stranded shortly after the FDNPP accident in 2011 may be related more to the contamination level of seawater along the travel route rather than to their trophic level. Further studies of the seasonal movement of fish and other prey species are necessary to confirm the estimated travel routes of these cetaceans. In addition, further analysis using ashed muscle samples is necessary to investigate the changes in ${ }^{134} \mathrm{Cs}$ and ${ }^{137} \mathrm{Cs}$ at low concentrations in cetaceans collected before and after the FDNPP accident, as well as to determine the fate of these radionuclides in the environment.

Acknowledgements. We thank Dr. Fukuda for his technical advice regarding radionuclide determination. We also thank Miss Funahashi (IFAW) for her mediating the photo of Pacific white-sided dolphin.

\section{LITERATURE CITED}

Amano M (1998) Distribution and migration of small odontocetes in the area where Kuroshio Current and Oyashio Current meet. Kaiyo 13:187-191

Amano M, Hayano A (2007) Intermingling of dalli-type Dall's porpoises into wintering truei-type population off Japan: implications from color patterns. Mar Mamm Sci 23:1-14

> Aoyama M, Tsumune D, Uematsu M, Kondo F, Hamajima Y (2012) Temporal variation of ${ }^{134} \mathrm{Cs}$ and ${ }^{137} \mathrm{Cs}$ activities in surface water at stations along the coastline near the Fukushima Dai-ichi Nuclear Power Plant accident site, Japan. Geochem J 46:321-325

> Berrow SD, Long SC, Pollard MD, Rogan E, Lockyer C (1998) Radionuclides $\left({ }^{137} \mathrm{Cs}\right.$ and $\left.{ }^{40} \mathrm{~K}\right)$ in harbour porpoise Phocoena phocoena from British and Irish coastal waters. Mar Pollut Bull 36:569-576

> Buesseler K, Aoyama M, Fukasawa M (2011) Impacts of the Fukushima Nuclear Power Plants on marine radioactivity. Environ Sci Technol 45:9931-9935

> Calmet D, Woodhead D, André JM (1991) ${ }^{210} \mathrm{~Pb},{ }^{137} \mathrm{Cs}$, and ${ }^{40} \mathrm{~K}$ in three species of porpoises caught in the eastern tropical Pacific Ocean. J Environ Radioact 15:153-169

> Endo T, Hisamichi Y, Kimura O, Haraguchi K and others (2010) Stable isotope ratios of carbon and nitrogen and mercury concentrations in 13 toothed whale species taken from the western Pacific Ocean off Japan. Environ Sci Technol 44:2675-2681

> Hayano A, Amano M, Miyazaki N (2003) Phylogeography and population structure of the Dall's porpoise, Phocoenoides dalli, in Japanese waters revealed by mitochondrial DNA. Genes Genet Syst 78:81-91

Honda M, Aono T, Aoyama M, Hamajima Y and others (2012) Dispersion of artificial cesium-134 and -137 in the western North Pacific one month after the Fukushima accident. Geochem J 46:e1-e9 
Inoue M, Kofuji H, Hamajima Y, Nagao S, Yoshida K, Yamamoto $\mathrm{M}$ (2012a) ${ }^{134} \mathrm{Cs}$ and ${ }^{137} \mathrm{Cs}$ activities in coastal seawater along Northern Sanriku and Tugaru Strait, northeastern Japan, after Fukushima Dai-ichi Nuclear Power Plant accident. J Environ Radioact 111:116-119

Inoue $M$, Kofuji $H$, Nagao $S$, Yamamoto $M$ and others (2012b) Low level of ${ }^{134} \mathrm{Cs}$ and ${ }^{137} \mathrm{Cs}$ in surface seawaters around the Japanese Archipelago after the Fukushima Dai-ichi Nuclear Power Plant accident in 2011. Geochem J 46:311-320

Inoue $\mathrm{M}$, Kofuji $\mathrm{H}$, Nagao $\mathrm{S}$, Yamamoto $\mathrm{M}$ and others (2012c) Lateral variation of ${ }^{134} \mathrm{Cs}$ and ${ }^{137} \mathrm{Cs}$ concentrations in surface seawater in and around the Japan Sea after the Fukushima Dai-ichi Nuclear Power Plant accident. J Environ Radioact 109:45-51

Kasamatsu F, Inatomi N (1998) Effective environmental halflives of ${ }^{90} \mathrm{Sr}$ and ${ }^{137} \mathrm{Cs}$ in the coastal seawater of Japan. J Geophys Res 103:1209-1217

Kasamatsu F, Ishikawa Y (1997) Natural variation of radionuclide ${ }^{137} \mathrm{Cs}$ concentration in marine organisms with special reference to the effect of food habits and trophic level. Mar Ecol Prog Ser 160:109-120

Kasamatsu K, Kawabe N, Inatomi N, Mutayama T (1999) A note of radionuclide ${ }^{137} \mathrm{Cs}$ and ${ }^{40} \mathrm{~K}$ concentrations in Dall's porpoises, Phocoenoides dalli, in coastal waters of Japan. J Cetacean Res Manag 1:275-278

Kishiro T (2007) Geographical variations in the external body proportion of Baird's beaked whales (Berardius bairdii) off Japan. J Cetacean Res Manag 9:89-93

Kofuji H, Inoue M (2013) Temporal variations in ${ }^{134} \mathrm{Cs}$ and ${ }^{137} \mathrm{Cs}$ concentrations in seawater along the Shimokita Peninsula and the northern Sanriku coast in northeastern Japan, one year after the Fukushima Dai-ichi

Editorial responsibility: Scott Shaffer,

San Jose, California, USA
Nuclear Power Plant accident. J Environ Radioact 124: 239-245

> Oikawa S, Watanabe T, Takata H, Suzuki C, Nakahara M, Misonoo J (2013) Long term temporal changes of ${ }^{90} \mathrm{Sr}$ and ${ }^{137} \mathrm{Cs}$ in seawater, bottom sediment and marine organism samples, from the Chernobyl accident to immediately after the Fukushima accident. Bunseki Kagaku 62:455-474

Takagi K, Fujimoto K, Watanabe T, Kaeriyama H and others (2014) Radiocesium concentration of small epipelagic fishes (sardine and Japanese anchovy) off Kashima-Boso area. Bull Jpn Soc Sci Fish 80:786-791

Tsutsui S, Tanaka M, Miyazaki N, Furuya T (2001) Pacific white-sided dolphin (Lagenorhynchus obliquidens) anomalous colour patterns in Volcano Bay, Hokkaido, Japan. Aquat Mamm 27:172-182

Wade PR, Brownell RL Jr, Kasuya T (2010) A review of the biology of western North Pacific minke whales relevant to stock structure. Report No. SC62/NPM13 (revised) to the IWC Scientific Committee, $62^{\text {nd }}$ International Whaling Commission meeting, Agadir, Morocco, 21-25 June 2010

> Watson WS, Sumner DJ, Baker JR, Kennedy S, Reid R, Robinson I (1999) Radionuclides in seals and porpoises in the coastal waters around the UK. Sci Total Environ 234:1-13

WHO (World Health Organization) (1989) Health hazards from radiocaesium following the Chernobyl nuclear accident: report on a WHO working group. J Environ Radioact 10:257-259

> Yoshitome R, Kunito T, Ikemoto T, Tanabe S, Zenke $\mathrm{H}_{\text {, }}$ Yamauchi M, Miyazaki N (2003) Global distribution of radionuclides $\left({ }^{137} \mathrm{Cs}\right.$ and $\left.{ }^{40} \mathrm{~K}\right)$ in marine mammals. Environ Sci Technol 37:4597-4602

Submitted: February 23, 2015; Accepted: July 19, 2015 Proofs received from author(s): August 25, 2015 